\title{
A New Approach to a Successful Management of Burning Mouth Syndrome Ihsan Abdullah Kumail
}

BDS MSc PhD Oral Medicine - Ass. prof/ College of Dentistry/ Muthanna University

\section{ABSTRACT}

Background: The accurate treatment of burning mouth syndrome (BMS) can be achieved just when the cause is properly identified. This study had been conducted to find out the relationship between symptoms and the causative factor(s) of the disease, so that to make successful treatment more easily reachable.

Method: The study was conducted with informed consent on 124 patients (63 females and 61 males, ages ranging from 39 to 66) complaining of burning mouth syndrome visited the Oral Medicine Clinic in Dentistry College/ Muthanna University and referred by dentists to private clinic for consultation from January 2014 to November 2016. Medical and social history was taken from each patient, haematological investigations and measurement of stimulated salivary flow rate were done for all patients. Intraoral exam was done for each patient to exclude any detectable lesion. Findings were recorded and matched with symptoms for each patient. Each patient received treatment according to diagnosis of causative factor(s) and 6 months follow up was done for each patient after initiation of treatment to evaluate the outcome of treatment and to confirm the accuracy of diagnosis in case of good response to treatment for each patient.

Results: Group A: no 41 subjects (33\% of all groups): complained of continuous symptomatic day with asymptomatic night, examination and investigations showed that 35 of them ( $85.4 \%$ of group A) were complaining of chronic anxiety and menopause women, while the rest 6 were of similar symptoms but due to different causative factor(s). Group B: Symptoms for one day with asymptomatic following days was the criteria of 27 subjects ( $21.8 \%$ of all groups), 22 of them ( $81.5 \%$ of group B) were with nutritional deficiency and good results were obtained after treatment, the rest 5 were with tongue thrust habit, psychotic and sharpness. Group C: No symptoms on waking which increase throughout the day was associated with 36 subjects ( $29 \%$ of all groups), 30 of them (83.3\%) suffer from dry mouth (diabetis, medications or age-related causes), the rest 6 patients complained of sharpness, ill fitted denture and menopause. Group D: Restricted night symptoms with inconstant day symptoms (no 20) (16.1\% of all groups), of whom, 18 were associated with sharpness and bad prosthesis (90\%) who showed excellent response after treatment, the rest 2 subjects complained of menopause and anxiety.

Conclusion: Each causative factor of burning mouth syndrome is characterized by specific criteria of symptoms differ from symptoms caused by another factor(s) which must determine treatment methods.

KEY WORDS:

Burning mouth syndrome, symptoms, causes.

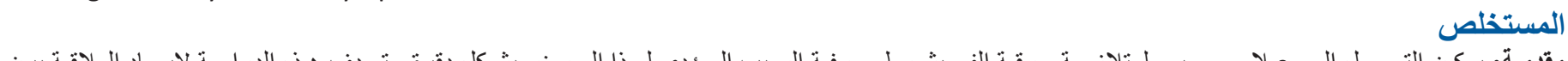

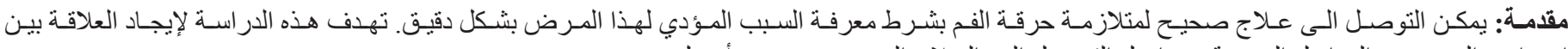

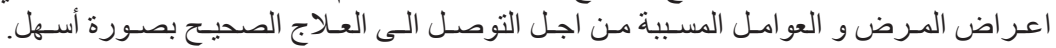

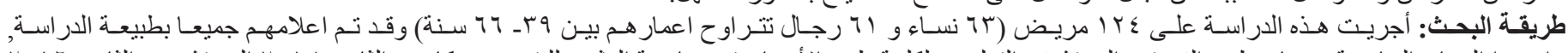

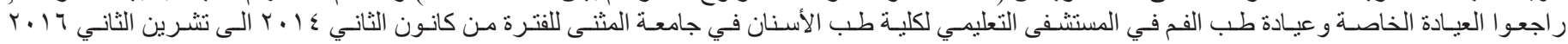

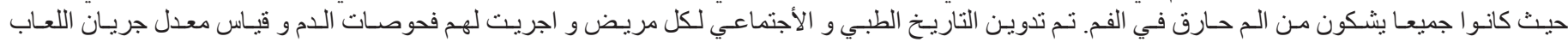

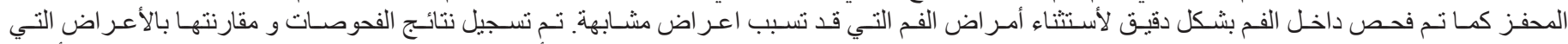

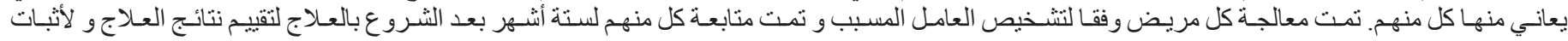

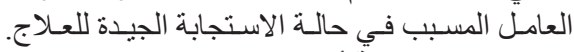

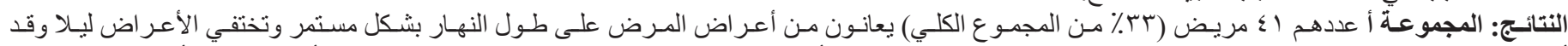

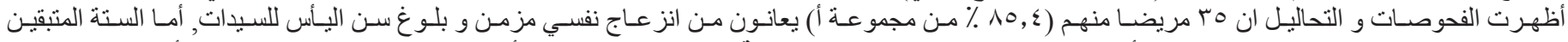

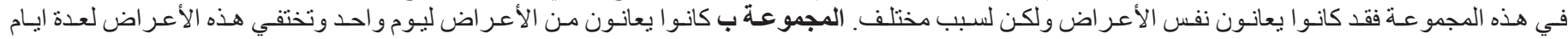

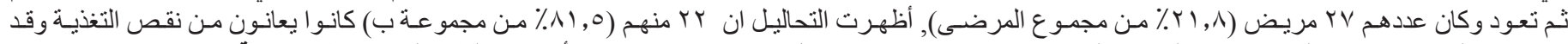

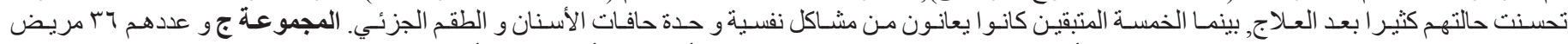

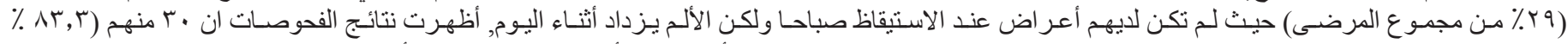

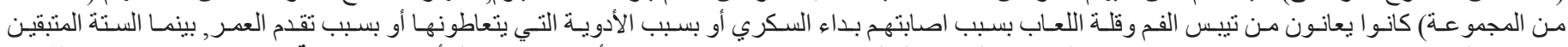

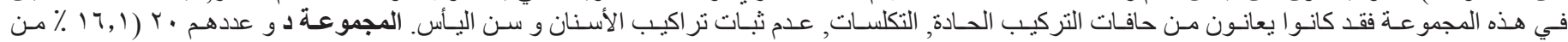

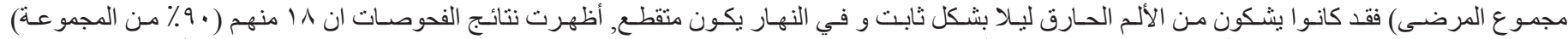

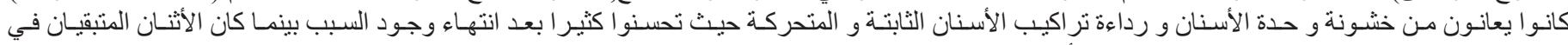

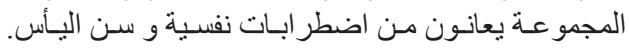

\section{INTRODUCTION}

Burning mouth syndrome (BMS) or glossodynia whether idiopathic or secondary is caractherized by bilateral burning sensation in a normal oral mucosa without any apparent oral lesion ${ }^{(1,2)}$. The tongue is the most commonly affected site, but the burning sensation has a chronic course and may affect any area of oral mucosa with variable intensities ${ }^{(3,4) . .}$ The well known

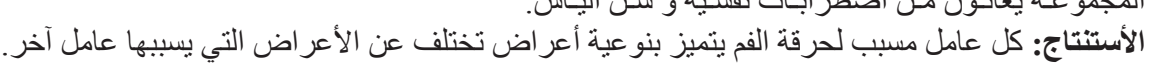
etiological factors of this syndrome are xerostomia or reduced salivary flow, although some studies predominate changes in salivary protein contents rather than quantity $(5,6,7)$, parafunctional habits (bruxism, clenching and tongue thrust ${ }^{(8)}$, depression, anxiety, emotional, social and financial stress and cancerphobia ( 7,910$)$, reduction in estrogen hormone in menopause women ${ }^{(11,12),}$ allergies ${ }^{(13)}$, nutritional 
or pathological deficiency of iron, folate and vitamin B12 ${ }^{(10),}$ The etiology of BMS is poorly understood and considered multifactorial, i e different factors may precipitate the condition which may increase the challenge for clinician to reach the most proper and accurate method of treatment for a particular patient, because each case requires a method of treatment differs from that which may treat another case of this syndrome according to etiological factor, hence, the need to a protocol that minimizes this difficulty in achieving the most appropriate treatment of this syndrome becomes important.

\section{PATIENTS AND METHODS}

This prospective study was done from January 2014 to November 2016 on 124 patients complaining of BMS ( 63 females and 61 males, ages ranged from 39- 66 years) visited Oral Medicine Clinic in Dentistry College/ Muthanna University and private clinic.

Examination procedure: Each patient was carefully examined extra and intra-orally for any detectable lesion, habits, paleness of mucosa, any roughness, sharpness or bad prosthesis that may precipitate the condition. A specialist psychiatrist*, physician** and gynaecologist*** were consulted for stopping, changing and/or adding medications on need. The intensity of burning sensation at the time of first visit for each patient was recorded on a visual analogue scale (VAS) ranging from 0 (no pain) to 10 (intolerable pain).

The following informations were taken from all patients:

- Details of medical history including any systemic disease, medication(s) taken and allergies. Dental history for any previous oral lesion or use of oral rinses

- Any oral habit like bruxism, clenching tongue bite and tongue thrust habits which could be estimated on intra-oral examination by wearing of cusps, rubbing or scarring of anterior part of tongue and protrusion of upper central incisors

- Feeling of dry mouth during day, or whether the patient is mouth breather at night

- Details of social, economic and emotional condition, personal mood and any type of phobia

- Precise description of pain regarding the time of onset, intensity, what time it may increase or decrease, duration, is pain was experienced at day or at night time, intermittent or continuous, if it is felt daily or not, any precipitating causes (e $\mathrm{g}$ stress, food).

- Hematologic investigations were performed for all patients including serum vit $\mathrm{B} 12, \mathrm{Hb}$ and fasting blood sugar for suspected subjects.

\section{Treatment}

Diagnosis of the causative factor(s) was made for each patient by exclusion method depending on findings appeared from examinations above, and according to this diagnosis, treatment and instructions were given for each patient. In patients who were taking medications causing burning sensation or dry mouth (e g ACEI, thyroxin, chemotherapy or they were diabetic, the consultant physician only agreed to change ACEI to Candesartan $16 \mathrm{mg}$ daily which does not cause dryness or burning sensation, Accordingly, sialogogue was prescribed for others. In patients on psychotropic medications, the consultant psychiatrist refused to change or reduce medications, so sialogogue was prescribed to them, for anxious patients, the psychiatrist recommended Buspiron 5-30 mg daily in divided doses (according to his instructions for each case) which is a new non-benzodiazepines anxiolytic (does not cause tolerance). Subjects who were proved diabetics were referred to their physicians for checking and more control of the disease to reduce mouth dryness as much as possible. Subjects who were suspicious to be diabetics were instructed to do fasting blood sugar, patients with elevated levels were referred to physicians for treatment.

Sialogogue Pilocarpine HCL tablets (Salagen R) (MGI Pharma, Inc. FDA approved since 1994) was prescribed to be taken $3-4$ times a day for 12 weeks after meals (the effect of this drug usually lasts from $2-4$ hours according to leaflet of drug) to increase salivary flow rate for patients suffering from xerostomia whether it's cause was due to agerelated dry mouth, proved diabetis, heavy smoking, psychotropic or anticholinergic and antihypertensive ( $\beta$ - blockers) medications, but it was not given for patients whose medications were changed or with nutritional difeciencies who were treated with triple therapy (B co, Fersolin and Folic acid tablets) for 6 months only ${ }^{(17) .}$ Patients with oral habits like tongue thrust or tongue biting were instructed to quit. In menopause women, estrogen replacement was achieved by giving them piperazine oestrone sulphate $1.25 \mathrm{mg}$ daily for 6 months with Medroxyprogesterone acetate $5 \mathrm{mg}$ once daily added at day 10 of replacement to prevent the estrogen from overgrowing the uterine

\footnotetext{
* Dr Amir Ammash (consultant psychiatrist and supervisor of psychiatric postgraduate students in Ibn Rushd teaching hospital).

**Dr Ali Yasin (consultant physician in medical city teaching hospital).

***Dr Lamia Al sa'di (consultant gynaecologist in Al Elwea teaching hospital).
} 
lining ${ }^{(20)}$ according to consultation of the specialist gynecologist. Smoothening of sharpness teeth and fillings was done. New partial and complete dentures were constructed for patients suffering from ill fitted prosthesis and all denture wearers were instructed to remove it at night and put it in chlorhexidine solution $0.12 \%$ during night ${ }^{(10)}$, bad bridges were removed. After treatment, all patients were examined twice at 3 months and 6 months periods and the severities of pain were recorded at the visual analogue scale for each patient and a comparison of three records on that scale was made to find out whether there is improvement or reduction in symptoms or not, on the other hand, this will give good evaluation about the efficacy of treatment as well as will confirm the

Table 1: Frequency distribution of the study sample by symptoms group. symptoms (group D).

\begin{tabular}{|c|c|c|}
\hline Groups & N & \% \\
\hline Continuous day symptoms with asymptomatic night & 41 & 33.1 \\
\hline Symptoms for one day with asymptomatic following days & 27 & 21.8 \\
\hline No symptoms on waking which increase throughout the day & 36 & 29 \\
\hline Restricted night symptoms and inconstant day symptoms & 20 & 16.1 \\
\hline Total & 124 & 100 \\
\hline
\end{tabular}

As shown in table (2), $90 \%$ of patients with anxiety and $81.8 \%$ of menopause women were in group A, $91.7 \%$ of patients with nutritional deficiencies were in group B, $91.3 \%$ of diabetic patients and all drugrelated hyposalivation patients were in group $C$, while

Table 2: The association of 4 symptoms categories with possible causes.

\begin{tabular}{|c|c|c|c|c|c|c|c|c|c|c|}
\hline \multirow{3}{*}{ Possible cause of symptoms } & \multicolumn{10}{|c|}{ Symptoms group } \\
\hline & \multicolumn{2}{|c|}{$\begin{array}{l}\text { Continuous day } \\
\text { symptoms with } \\
\text { asymptomatic } \\
\text { night }\end{array}$} & \multicolumn{2}{|c|}{$\begin{array}{l}\text { Symptoms for } \\
\text { one day with } \\
\text { asymptomatic } \\
\text { following days }\end{array}$} & \multicolumn{2}{|c|}{$\begin{array}{c}\text { No symptoms on } \\
\text { waking which } \\
\text { increase } \\
\text { throughout the day }\end{array}$} & \multicolumn{2}{|c|}{$\begin{array}{c}\text { Restricted } \\
\text { night } \\
\text { symptoms and } \\
\text { inconstant day } \\
\text { symptoms }\end{array}$} & \multicolumn{2}{|c|}{ Total } \\
\hline & $N$ & $\%$ & $N$ & $\%$ & $N$ & $\%$ & $N$ & $\%$ & $N$ & $\%$ \\
\hline Anxiety & 27 & 90 & 2 & 6.7 & 0 & 0 & 1 & 3.3 & 30 & 100 \\
\hline Menopause & 9 & 81.8 & 0 & 0 & 1 & 9.1 & 1 & 9.1 & 11 & 100 \\
\hline $\mathrm{DM}$ & 1 & 4.3 & 1 & 4.3 & 21 & 91.3 & 0 & 0 & 23 & 100 \\
\hline Nutritional & 2 & 8.3 & 22 & 91.7 & 0 & 0 & 0 & 0 & 24 & 100 \\
\hline Mechanical & 0 & 0 & 2 & 11.1 & 2 & 11.1 & 14 & 77.8 & 18 & 100 \\
\hline $\begin{array}{l}\text { Drug related (ACEI, } \\
\text { Thyroxine, Psychotroic) }\end{array}$ & 0 & 0 & 0 & 0 & 7 & 100 & 0 & 0 & 7 & 100 \\
\hline Others & 2 & 18.2 & 0 & 0 & 5 & 45.5 & 4 & 36.4 & 11 & 100 \\
\hline
\end{tabular}

$77.8 \%$ of patients with sharp teeth or restorations, ill fitted prosthesis and bad bridges were in group D. This may give us an impression about the relation of each criteria of symptoms to a precipitating factor.

As shown in table (1), results showed that 41 patients (mean age 55.26) were complaining of continuous day symptoms with asymptomatic night (group A), 27 patients (mean age 49.1) complain of symptoms for one day with asymptomatic following days (group B), 36 patients (mean age 55.3) have no symptoms on waking, but they experience burning sensation later which increases throughout the day (group C), and 20 patients (mean age 49.4) complain of restricted night symptoms and inconsistent day 
Table 3: Frequency distribution of the study sample by possible cause and treatment.

\begin{tabular}{|c|}
\hline N=124 \\
\hline Possible cause \\
\hline Anxiety \\
Menopause \\
DM \\
Nutritional \\
Sharpness \\
\hline Drug related (ACEI, Thyroxine, Psychotroic) \\
Heavy smoker \\
Habitual \\
\hline Age-related hyposalivation \\
Total
\end{tabular}

\begin{tabular}{|c|}
\hline$N$ \\
\hline 30 \\
\hline 11 \\
\hline 23 \\
\hline 24 \\
\hline 22 \\
\hline 7 \\
\hline 2 \\
\hline 1 \\
\hline 4 \\
\hline
\end{tabular}

\begin{tabular}{|c|c|}
\hline Treatment & $\%$ \\
\hline Buspirone & 24.2 \\
\hline Estrogen & 8.9 \\
\hline Sialogogue & 18.5 \\
\hline Triple & 19.4 \\
\hline Removal & 17.7 \\
\hline Change \& sialog & 5.6 \\
\hline Quit, cessation & 1.6 \\
\hline quit & 0.8 \\
\hline Sialogopue & 3.2 \\
\hline
\end{tabular}

After careful intraoral examination, thorough medical and dental history, hematologic investigations and consultations, treatment was performed for each patient according to causative factor, as shown in

table (3) which describes the number and percentage of patients for each causative factor and treatment for each.

Table 4: The mean visual analogue scale and changes after treatment by possible cause.

\begin{tabular}{|c|}
\hline Possible cause of symptoms \\
\hline Anxiety \\
Range \\
Median \\
\hline Interquartile range \\
\hline N \\
\hline (Wilcoxon signed rank test $)=$ \\
\hline Menopause \\
Range \\
Median \\
\hline Interquartile range \\
N \\
\hline P (Wilcoxon signed rank test $)=$ \\
\hline DM \\
Range \\
\hline Median \\
\hline Interquartile range \\
N \\
\hline P (Wilcoxon signed rank test $)=$ \\
Nutritional \\
Range \\
Median \\
\hline Interquartile range \\
\hline Mechanical \\
\hline (Wilcoxon signed rank test $)=$ \\
\hline
\end{tabular}

\begin{tabular}{|c|c|c|c|c|c|}
\hline \multicolumn{6}{|c|}{ Visual analog score } \\
\hline $\begin{array}{l}\text { at baseline } \\
\text { (before } \\
\text { treatment) }\end{array}$ & $\begin{array}{l}\text { after } 3 \\
\text { months }\end{array}$ & $\begin{array}{c}\text { changes after } 3 \\
\text { months compared } \\
\text { to baseline }\end{array}$ & $\begin{array}{c}\text { after } 6 \\
\text { months }\end{array}$ & $\begin{array}{c}\text { changes after } 6 \\
\text { months compared } \\
\text { to baseline }\end{array}$ & $\begin{array}{c}\text { Mean } \\
\text { rank }\end{array}$ \\
\hline & & & & & 59.3 \\
\hline (4 to 8 ) & (2 to 7$)$ & $(-3$ to -1$)$ & (1 to 6$)$ & $(-6$ to -2$)$ & \\
\hline 6 & 4 & -2 & 3 & -3 & \\
\hline (5 to 7 ) & (3 to 4$)$ & $(-3$ to -1$)$ & (2 to 3 ) & $(-4$ to -3$)$ & \\
\hline \multirow[t]{3}{*}{30} & 30 & 30 & 30 & 30 & \\
\hline & & $<0.001$ & & $<0.001$ & \\
\hline & & & & & 102.23 \\
\hline (5 to 9 ) & (4 to 8 ) & $(-2$ to 0$)$ & (3 to 8 ) & $(-3$ to 0$)$ & \\
\hline 7 & 6 & -1 & 4 & -1 & \\
\hline (6 to 7 ) & (4 to 7 ) & $(-2$ to 0$)$ & (4 to 7 ) & $(-3$ to -1$)$ & \\
\hline \multirow[t]{3}{*}{11} & 11 & 11 & 11 & 11 & \\
\hline & & $0.009(\mathrm{NS})$ & & $0.007(\mathrm{NS})$ & \\
\hline & & & & & 78.46 \\
\hline (4 to 9 ) & (3 to 6$)$ & $(-3$ to 0$)$ & (1 to 5$)$ & $(-5$ to 0$)$ & \\
\hline 6 & 4 & -1 & 4 & -3 & \\
\hline ( 5 to 7 ) & (4 to 5 ) & $(-2$ to -1$)$ & (2 to 4$)$ & $(-3$ to -2$)$ & \\
\hline \multirow[t]{3}{*}{23} & 23 & 23 & 23 & 23 & \\
\hline & & $<0.001$ & & $<0.001$ & \\
\hline & & & & & 58.94 \\
\hline (3 to 8 ) & (2 to 6$)$ & $(-3$ to 0$)$ & (0 to 3$)$ & $(-6$ to -2$)$ & \\
\hline 6 & 4 & -1 & 2 & -3 & \\
\hline (4 to 6 ) & (3 to 5$)$ & $(-2$ to -1$)$ & (1 to 3$)$ & $(-4$ to -2$)$ & \\
\hline \multirow[t]{3}{*}{24} & 24 & 24 & 24 & 24 & \\
\hline & & $<0.001$ & & $<0.001$ & \\
\hline & & & & & 40.92 \\
\hline
\end{tabular}




\begin{tabular}{|c|c|c|c|c|c|c|}
\hline & \multicolumn{6}{|c|}{ Visual analog score } \\
\hline Possible cause of symptoms & $\begin{array}{l}\text { at baseline } \\
\text { (before } \\
\text { treatment) }\end{array}$ & $\begin{array}{l}\text { after } 3 \\
\text { months }\end{array}$ & $\begin{array}{c}\text { changes after } 3 \\
\text { months compared } \\
\text { to baseline }\end{array}$ & $\begin{array}{l}\text { after } 6 \\
\text { months }\end{array}$ & $\begin{array}{c}\text { changes after } 6 \\
\text { months compared } \\
\text { to baseline }\end{array}$ & $\begin{array}{c}\text { Mean } \\
\text { rank }\end{array}$ \\
\hline Range & (4 to 7 ) & $(1$ to 6$)$ & $(-4$ to -1$)$ & $(0$ to 5$)$ & $(-7$ to -2$)$ & \\
\hline Median & 5 & 2 & -3 & 1 & -4 & \\
\hline Interquartile range & $(5$ to 6$)$ & $(2$ to 4$)$ & $(-4$ to -2$)$ & (1 to 2 ) & $(-5$ to -3$)$ & \\
\hline $\mathrm{N}$ & 18 & 18 & 18 & 18 & 18 & \\
\hline $\mathrm{P}($ Wilcoxon signed rank test $)=$ & & & $<0.001$ & & $<0.001$ & \\
\hline $\begin{array}{c}\text { Drug related (ACEI, Thyroxine, } \\
\text { Psychotroic) }\end{array}$ & & & & & & 52.64 \\
\hline Range & (5 to 8$)$ & $(2$ to 6$)$ & $(-4$ to -1$)$ & $(0$ to 6$)$ & $(-6$ to -2$)$ & \\
\hline Median & 6 & 4 & -2 & 2 & -4 & \\
\hline Interquartile range & $(5$ to 6$)$ & (2 to 5$)$ & $(-3$ to -1$)$ & (1 to 3 ) & $(-4$ to -3$)$ & \\
\hline $\mathrm{N}$ & 7 & 7 & 7 & 7 & 7 & \\
\hline $\mathrm{P}($ Wilcoxon signed rank test $)=$ & & & 0.017 & & 0.017 & \\
\hline Others & & & & & & 47.5 \\
\hline Range & (4 to 6$)$ & (1 to 5$)$ & $(-5$ to 0$)$ & $(0$ to 5$)$ & $(-6$ to 0$)$ & \\
\hline Median & 5 & 2 & -3 & 1 & -4 & \\
\hline Interquartile range & $(5$ to 6$)$ & (1 to 3 ) & $(-3$ to -2$)$ & (0 to 3$)$ & $(-4$ to -3$)$ & \\
\hline $\mathrm{N}$ & 11 & 11 & 11 & 11 & 11 & \\
\hline $\mathrm{P}($ Wilcoxon signed rank test $)=$ & & & 0.004 & & 0.004 & \\
\hline $\begin{array}{l}\mathrm{P}(\text { Kruskal-Wallis test }) \text { for differ- } \\
\text { ence in median }=\end{array}$ & 0.02 & & & & & $<0.001$ \\
\hline
\end{tabular}

Table 5: The mean visual analogue scale and changes after treatment by symptoms group.

\begin{tabular}{|c|c|c|c|c|c|c|}
\hline & \multicolumn{6}{|c|}{ Visual analog score } \\
\hline Symptoms group & $\begin{array}{l}\text { at baseline } \\
\text { (before } \\
\text { treatment) }\end{array}$ & $\begin{array}{l}\text { after } 3 \\
\text { months }\end{array}$ & $\begin{array}{c}\text { changes after } \\
3 \text { months } \\
\text { compared to } \\
\text { baseline }\end{array}$ & $\begin{array}{l}\text { after } 6 \\
\text { months }\end{array}$ & $\begin{array}{c}\text { changes } \\
\text { after } 6 \\
\text { months } \\
\text { compared } \\
\text { to baseline }\end{array}$ & $\begin{array}{c}\text { Mean } \\
\text { rank }\end{array}$ \\
\hline $\begin{array}{c}\text { Continuous day symptoms with } \\
\text { asymptomatic night }\end{array}$ & & & & & & 68.89 \\
\hline Range & (4 to 9 ) & $(2$ to 8$)$ & $(-3$ to 0$)$ & (1 to 8$)$ & $(-5$ to 0$)$ & \\
\hline Median & 6 & 4 & -2 & 3 & -3 & \\
\hline Interquartile range & (5 to 7$)$ & $(4$ to 5$)$ & $(-2$ to -1$)$ & (2 to 4$)$ & $(-4$ to -2$)$ & \\
\hline $\mathrm{N}$ & 41 & 41 & 41 & 41 & 41 & \\
\hline$P($ Wilcoxon signed rank test $)=$ & & & $<0.001$ & & $<0.001$ & \\
\hline $\begin{array}{l}\text { Symptoms for one day with as- } \\
\text { ymptomatic following days }\end{array}$ & & & & & & 58.56 \\
\hline Range & (3 to 8$)$ & $(2$ to 6$)$ & $(-3$ to 0$)$ & (0 to 3$)$ & $(-6$ to -2$)$ & \\
\hline Median & 5 & 4 & -1 & 2 & -3 & \\
\hline Interquartile range & (4 to 6$)$ & $(3$ to 4$)$ & $(-2$ to -1$)$ & (1 to 3$)$ & $(-4$ to -2$)$ & \\
\hline $\mathrm{N}$ & 27 & 27 & 27 & 27 & 27 & \\
\hline$P($ Wilcoxon signed rank test $)=$ & & & $<0.001$ & & $<0.001$ & \\
\hline $\begin{array}{l}\text { No symptoms on waking which } \\
\text { increase throughout the day }\end{array}$ & & & & & & 72.36 \\
\hline
\end{tabular}




\begin{tabular}{|c|c|c|c|c|c|c|}
\hline & \multicolumn{6}{|c|}{ Visual analog score } \\
\hline Symptoms group & $\begin{array}{l}\text { at baseline } \\
\text { (before } \\
\text { treatment) }\end{array}$ & $\begin{array}{l}\text { after } 3 \\
\text { months }\end{array}$ & $\begin{array}{c}\text { changes after } \\
3 \text { months } \\
\text { compared to } \\
\text { baseline }\end{array}$ & $\begin{array}{l}\text { after } 6 \\
\text { months }\end{array}$ & $\begin{array}{c}\text { changes } \\
\text { after } 6 \\
\text { months } \\
\text { compared } \\
\text { to baseline }\end{array}$ & $\begin{array}{c}\text { Mean } \\
\text { rank }\end{array}$ \\
\hline Range & (4 to 9 ) & $(2$ to 6$)$ & $(-4$ to 0$)$ & $(0$ to 6$)$ & $(-6$ to 0$)$ & \\
\hline Median & 6 & 4 & -2 & 3 & -3 & \\
\hline Interquartile range & (5 to 7$)$ & (3 to 5$)$ & $(-3$ to -1$)$ & (2 to 4$)$ & $(-4$ to -2$)$ & \\
\hline $\mathrm{N}$ & 36 & 36 & 36 & 36 & 36 & \\
\hline$P($ Wilcoxon signed rank test $)=$ & & & $<0.001$ & & $<0.001$ & \\
\hline $\begin{array}{l}\text { Restricted night symptoms and } \\
\text { inconstant day symptoms }\end{array}$ & & & & & & 36.98 \\
\hline Range & (4 to 7 ) & (1 to 7$)$ & $(-5$ to 0$)$ & (0 to 6$)$ & $(-7$ to -1$)$ & \\
\hline Median & 5 & 2 & -3 & 1 & -4 & \\
\hline Interquartile range & (5 to 6$)$ & (1 to 3$)$ & $(-4$ to -3$)$ & (0 to 1$)$ & $(-5$ to -4$)$ & \\
\hline $\mathrm{N}$ & 20 & 20 & 20 & 20 & 20 & \\
\hline$P($ Wilcoxon signed rank test $)=$ & & & $<0.001$ & & $<0.001$ & \\
\hline $\begin{array}{l}\text { P (Kruskal-Wallis test) for } \\
\text { difference in median }=\end{array}$ & & & & & & 0.002 \\
\hline
\end{tabular}

The changes in mean visual analogue scale after 3 and 6 months of treatment by possible cause showed a significant reduction $\mathrm{P}<0.001$ compared to base line $\left(1^{\text {st }}\right.$ visit) except for menopause women which was non significant, as shown in table (4), while changes in the mean visual analogue scale of symptoms for all groups were all significant $\mathrm{P}<0.001$ after 3 and 6 months treatment compared to base line as shown in table (5). The changes in mean VAS for all patients (no 124) after 3 and 6 months were significant $\mathrm{P}<0.001$ compared to base line as shown in table (6) and figure (1). Those results confirm the diagnosis and revealed that the treatment for each causative factor was accurate.

Table 6: The mean visual analogue score and changes after treatment.

\begin{tabular}{|c|c|c|c|c|c|c|}
\hline & \multicolumn{6}{|c|}{ Visual analog score } \\
\hline Overall & $\begin{array}{c}\text { at baseline } \\
\text { (before treatment) }\end{array}$ & $\begin{array}{l}\text { after } 3 \\
\text { months }\end{array}$ & $\begin{array}{c}\text { changes after } \\
3 \text { months } \\
\text { compared to } \\
\text { baseline }\end{array}$ & $\begin{array}{l}\text { after } 6 \\
\text { months }\end{array}$ & $\begin{array}{c}\text { changes after } \\
6 \text { months } \\
\text { compared to } \\
\text { baseline }\end{array}$ & $\begin{array}{c}\text { Mean } \\
\text { rank }\end{array}$ \\
\hline Range & (3 to 9$)$ & (1 to 8$)$ & $(-5$ to 0$)$ & $(0$ to 8$)$ & $(-7$ to 0$)$ & \\
\hline Median & 6 & 4 & -2 & 2 & -3 & \\
\hline Interquartile range & (5 to 7$)$ & (3 to 5$)$ & $(-3$ to -1$)$ & (1 to 3$)$ & $(-4$ to -2$)$ & \\
\hline $\mathrm{N}$ & 124 & 124 & 124 & 124 & 124 & \\
\hline$P($ Wilcoxon signed rank test $)=$ & & & $<0.001$ & & $<0.001$ & \\
\hline
\end{tabular}


Medians (error bars: 25-75 percentiles)

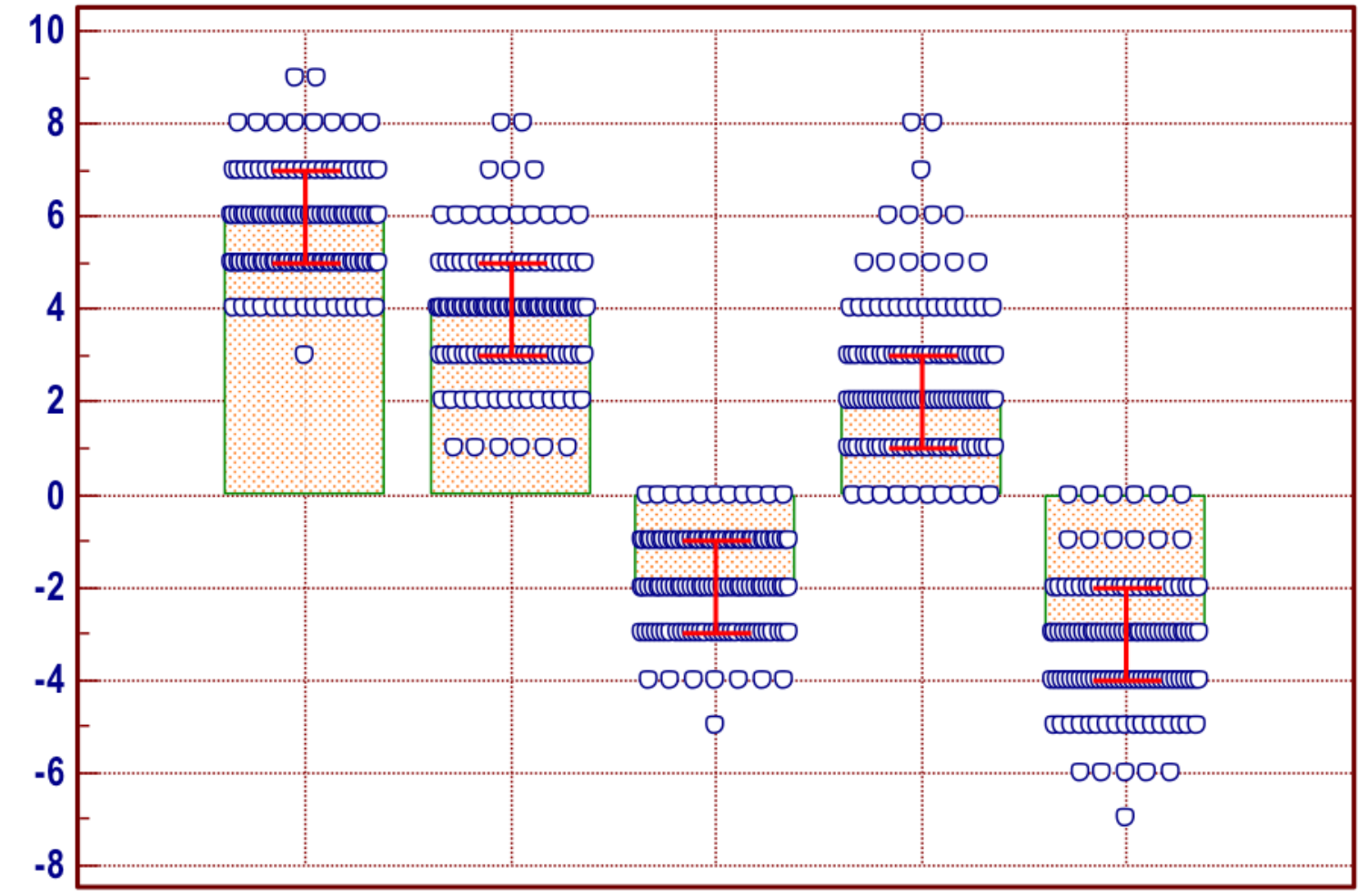

Vaisual analog score after 3 months of treament

Figure 1: The mean visual analogue score for all patients and changes after treatment compared to base line with interquartile range.

\section{DISCUSSION}

Menopause is associated with burning mouth syndrome (BMS), and the mechanism is unclear. Estrogen has documented effects on oral mucosa, and reduction may lead to atrophic changes thereby altering stimulation of the nerve endings within the

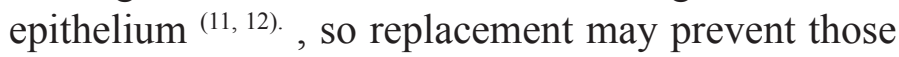
changes resulting in reduction of symptoms. In this study many of them did not respond to treatment and this comes in line with many previous studies which stated that there may be moderate reduction in symptoms of some while others did not respond to treatment $(11,20)$.

Peripheral neuropathy secondary to DM is a cause of secondary burning mouth syndrome (BMS) which may be due to improper signaling carried along sensory nerve fibers or due to deepethlialization caused by dry mouth induced by $\mathrm{DM}^{(1,18)}$, so referring them to their physicians to more control of the disease and stimulation of salivation by sialogogues were the appropriate choice in reducing the intensity of burning mouth sensation.

Nicotinic acid in heavy smokers is a well known mucosal irritant which may lead to BMS (5), so cessation of smoking may contribute to reduction of burning mouth sensation in those subjects.

Deficiencies of B vitamins 1, 2, 6, and 12, as well as zinc, folate and iron, have been suggested as causes of secondary burning mouth syndrome (BMS), either from direct neurologic damage or in relation to anemia or due to impaired renewal of epithelial lining (10), so replacement of those deficiencies by triple therapy and encouraging patients to eat specific foods and vegetables along 6 months resulted in excellent reduction in symptoms.

Anxiety is usually considered an exacerbating factor, rather than a cause of the chronic pain picture of burning mouth syndrome (BMS) (7). Cases of spontaneous resolution of symptoms after positive life events have been reported ${ }^{(10)}$, this may explain the action of anxiolytic medications in restoring a positive mood of life and subsequent reduction in symptoms. Patients with burning mouth syndrome (BMS) may also have increased salivary cortisol relative to controls, indicative of higher levels of stress ${ }^{(9)}$ A proportion of patients have anxiety centered around concerns of cancer, or cancerphobia, at this point, the nature of the association between burning mouth syndrome (BMS) and anxiety is not clear ${ }^{(10) .}$

The most commonly noted medication associated with BMS is ACE inhibitors ${ }^{(15,21)}$ which may lead to an increase in salivary bradykinin which contains kallikrein (a molecule active in the kinin inflammatory pathway) resulting in oral burning symptoms ${ }^{(22)}$. Endogenous or reactive depression as well as anxiety 
are associated with serotonin deficiency which has been suggested as a possible mechanism for sensory alterations in burning mouth syndrome (BMS) because of its role in the descending inhibition of pain (23). , also psychotropic medications result in reduced salivary flow and subsequent burning sensation ${ }^{(23)}$, so sialogogues were the choice to enhance flow of saliva and reduce symptoms. Allergies are associated with signs of mucosal irritation which may be due to dental materials such as mercury (present in amalgam), methyl methacrylate (acrylic prosthesis) ${ }^{(13)}$

Thyroxines have also been implicated in burning mouth syndrome (BMS), hypothyroidism may cause peripheral neuropathy which may results in BMS (24). Although whether the medication itself or the underlying hypothyroidism is the cause is unclear ${ }^{(25)}$.

Bad oral habits like tongue biting or thrust may cause deepithelialization of the tongue and reactive stimulation to underlying trigeminal sensory fibers which may result in burning sensation (26).

Sialogogue increases the flow of saliva by stimulating parasympathetic activity in patients with peripheral neuropathy, drug related oral dryness and age related reduction of acinar cells ${ }^{(27)}$. But they have no effect after destruction of acinar cells (saliva producing cells) like what occurs after high dose irradiation and chemotharapy (27).

\section{CONCLUSION:}

Each causative factor of burning mouth syndrome is characterized by specific symptoms differ from symptoms caused by another factor(s).

Continuous symptomatic day with asymptomatic night was mainly the criteria of patients associated with chronic anxiety and menopause women.

Symptoms for one day with asymptomatic following days was mainly the criteria of nutritional deficiency and tongue thrust habit.

No symptoms on waking which increase throughout the day is associated with reduced salivary flow rate whether physiologic (aging) or to underlying disease like hypothyroidism, DM and medications taken like psychotropic, anticholinergic and antihypertensive.

Restricted night symptoms with inconstant day symptoms were associated with bad prosthesis, bad and rough restorations and teeth and may be allergies.

\section{REFERENCES}

1. Basker RM, Sturdee DW, Davenport JC. Patients with burning mouth. A clinical investigation of causative factors, including the climateric and diabetes. Br Dent $\mathrm{J}$ 1978;145:9-16.

2. Bergdahl M, Bergdahl J. Burning mouth syndrome: prevalence and associated factors. J Oral Pathol Med
2010;28:350-354.

3. Femiano F, Gombos F, Scully C, Busciolano M, De Luca P. Burning Mouth Syndrome (BMS): controlled open trial the efficacy of alpha-lipoic acid (thioctic acid) on symptomatology. Oral Diseases 2011;6:274-277.

4. Formaker Bk, Frank ME. Taste function in patients with oral burning. Chem Senses 2012;25:575-581.

5. Huang W, Rothe MJ, Grant-Kels JM. The burning mouth syndrome. J Am Acad Dermatol. Jan 2013;34(1):91-8

6. de Moura SA, de Sousa JM, Lima DF, et al. Burning mouth syndrome (BMS): sialometric and sialochemical analysis and salivary protein profile. Gerodontology. Sep $2012 ; 24$ (3): 173-6.

7. Bergdahl M, Bergdahl J. Burning mouth syndrome: prevalence and associated factors. J Oral Pathol Med. Sep 2011;28(8):350-4

8. Paterson AJ, Lamb AB, Clifford TJ, et al. Burning mouth syndrome: the relationship between the HAD scale and parafunctional habits. J Oral Pathol Med. Aug 2010;24(7):289-92

9. Amenabar JM, Pawlowski J, Hilgert JB, et al. Anxiety and salivary cortisol levels in patients with burning mouth syndrome: case-control study. Oral Surgery, Oral Medicine, Oral Pathology, Oral Radiology and Endodontics. April/2011;105:461-465.

10. Lamey PJ, Lamb AB. Prospective study of aetiological factors in burning mouth syndrome. Br Med J (Clin Res Ed). Apr 30 2012;296(6631):1243-6.

11. Välimaa H, Savolainen S, Soukka T, et al. Estrogen receptor-beta is the predominant estrogen receptor subtype in human oral epithelium and salivary glands. J Endocrinol. Jan 2014;180(1):55-62.

12. Wardrop RW, Hailes J, Burger H, et al. Oral discomfort at menopause. Oral Surg Oral Med Oral Pathol. May 2012;67(5):535-40

13. Koike M. [A case of burning mouth associated with dental metal allergy]. Nihon Hotetsu Shika Gakkai Zasshi. Jun 2012;49(3):498-501

14. Culhane NS, Hodle AD. Burning mouth syndrome after taking clonazepam. Ann Pharmacother. JulAug 2011;35(7-8):874-6,

15. Salort-Llorca C, Minguez-Serra MP, Silvestre FJ. Druginduced burning mouth syndrome: a new etiological diagnosis. Med Oral Patol Oral Cir Bucal. Mar $12013 ; 13(3):$ E $167-70$

16.

17. Sardella A, Lodi G, Demarosi F, et al. Causative or precipitating aspects of burning mouth syndrome: a casecontrol study.J Oral Pathol Med.Sep2011;35(8):466-71

18. Moore PA, Guggenheimer J, Orchard T. Burning mouth syndrome and peripheral neuropathy in patients with type 1 diabetes mellitus. J Diabetes Complications. NovDec 2012;21(6):397-402

19. Chisholm DM, Mason DK. Salivary glands in health and disease. London: Saunders, 2010: 228-30.

20. Tarkkila L, Linna M, Tiitinen A, et al. Oral symptoms at menopause--the role of hormone replacement therapy. Oral Surg Oral Med Oral Pathol Oral Radiol Endod. Sep 2011;92(3):276-80)

21. Brown R, Krakow AM, Douglas T, Chokki SK. 'Scalded mouth syndrome' caused by angiotensin converting enzyme inhibitors. Oral Surg Oral Med Oral Pathol Oral Radiol Endod. 2012;83:6657 
22. Loeb LM, Naffah-Mazzacoratti MG, Porcionatto MA, et al. Chondroitin sulfate and kallikrein in saliva: Markers for glossodynia. International Immunopharmacology. July 2013;8:1056-1058

23. Rojo L, Silvestre FJ, Bagan JV, De Vicente T. Psychiatric morbidity in burning mouth syndrome. Psychiatric interview versus depression and anxiety scales. Oral Surg Oral Med Oral Pathol. 2013;75:308-11

24. Ropper AH, et al. Adams \& Victor's Principles of Neurology; 2010 9th ed. New York, N.Y.: McGraw-Hill
25. Femiano F, Lanza A, Buonaiuto C, et al. Burning mouth syndrome and burning mouth in hypothyroidism: proposal for a diagnostic and therapeutic protocol. Oral Surgery, Oral Medicine, Oral Pathology, Oral Radiology and Endodontics. January/2013;105:E22-27

26. Lauria G, Majorana A, Borgna M, et al. Trigeminal small-fiber sensory neuropathy causes burning mouth syndrome. Pain. Jun 2011;115(3):332-7

27. Scala A, Checchi L, Montevecchi M, et al. Update on burning mouth syndrome: overview and patient management. Crit Rev Oral Biol Med. 2013;14(4):275-91 